\title{
SOME REMARKS ON THE TEXTS BY FOREIGNERS ON JAPAN UP TO THE END OF THE NINETEENTH CENTURY. HOW THEY CHANGED THE IMAGE OF JAPAN ABROAD AND THE IMPACT THEY HAD ON THE LANDSCAPE SENSIBILITIES OF THE JAPANESE
}

\author{
KEIICHI TAKEUCHI ${ }^{1}$
}

\begin{abstract}
In this paper, the author outlines the accounts, including pictures and photographs, of foreigners in Japan to point out some problems regarding the image of Japan as perceived by foreigners, especially Westerners. During the isolationist policy of the seventeenth to the middle of the nineteenth century, a certain amount of information on Japan trickled from time to time into the Western world through the Dutch, but these accounts did not present the orientalist and "masculine" image of the geisha, an image that came to the popularized in Western orientalist literature only in the second half of the nineteenth century. The volume on Japan by Élisée Reclus represents the highest achievement of the systematization of geographical knowledge in the 1880s. It was the texts penned by foreign residents in Japan that to some extent helped to transform the landscape sensibility of the Japanese people.
\end{abstract}

Key-words: Foreigners Japanese image, Western orientalist literature, Reclus, transformation of landscape Japanese sensibility, Shigetaka Shiga

Résumé: QUELQUES REMARQUES SUR LES TEXTES D’ÉTRANGERS SUR LE JAPON JUSQU'A LA FIN DU XIX ${ }^{\mathrm{e}}$ SIECle. COMMENT ILS ONT CHANGE L'IMAGE DU JAPON A L'ÉTRANGER ET LA SENSIBILITE PAYSAGERE CHEZ LES JAPONAIS - Dans cet article, l'auteur analyse divers documents, y compris tableaux et photos, pour montrer certains problèmes concernant l'image du Japon telle que l'avaient les étrangers, surtout les occidentaux. Durant la période d'isolationnisme du dix-septième à la moitié du dix-neuvième siècle, un certain nombre de renseignements sur le Japon parvenait de temps en temps dans le monde occidental par le biais des Hollandais, mais ces informations n'intégraient pas l'image orientaliste et "masculiniste" de la geisha, une représentation qui n'est devenue populaire dans la littérature occidentale sur l'Orient que dans la seconde moitié du dix-neuvième siècle. Le volume sur le Japon d'Élisée Reclus représente la plus importante systématisation de connaissances géographiques des années 1880. Ce sont les textes

1 Komazawa University, 4-14-23 Higashi Kunitachi 1860002, Japan.

Tel.: +81 42577 2727; Fax: +81 42576 7066; E-mail: taktakkm@ma.kcom.ne.jp 
écrits par les résidents étrangers au Japon qui, dans une certaine mesure, ont contribué au changement de la sensibilitè paysagère chez les Japonais.

Mots-clés: images étrangères du Japon, orientalisme littéraire occidental, Reclus, Shigetaka Shiga, transformation de la sensibilité paysagère japonaise.

Resumo: ALGUMAS OBSERVAÇÕES ACERCA DE TEXTOS DE ESTRANGEIROS SOBRE O JAPÃO ATÉ FINAIS DO SÉCULO XIX. COMO ALTERARAM A IMAGEM DO JAPÃO NO EXTERIOR E INTERFERIRAM NA SENSIBILIDADE PAISAGÍSTICA DOS JAPONESES - Neste artigo, o autor analisa diversos documentos, incluindo quadros e fotografias, para mostrar certos problemas ligados à imagem que os estrangeiros, sobretudo os ocidentais, tinham do Japão. Durante o período de isolacionismo que decorreu do século XVII até meados do século XIX, chegavam ao mundo ocidental, essencialmente através dos holandeses, um certo número de informações sobre o Japão. Estes relatos não incluíam a imagem oriental e "masculina" da geisha, que só foi popularizada na literatura ocidental sobre o Oriente na segunda metade do século XIX. O volume sobre o Japão de Élisée Reclus, representa a mais importante sistematização dos conhecimentos geográficos dos anos de 1880. Foram os textos escritos pelos estrangeiros residentes no Japão que, em certa medida, contribuíram para alterar a sensibilidade paisagística dos japoneses.

Palavras-chave: Imagens estrangeiras do Japão, literatura orientalista ocidental, Reclus, Shigetaka Shiga, transformação da sensibilidade paisagística japonesa.

\section{1 - GEOGRAPHICAL KNOWLEDGE OF JAPAN IN THE WESTERN WORLD BEFORE THE MIDDLE OF THE NINETEENTH CENTURY}

In Chinese documents, information concerning Japan began to appear from the third century on, and since then, cultural and personal exchanges have continued to be maintained, though the frequency and intensity of these exchanges differ according to the temper of the times.

In the West, as is widely known, the first information on Japan was furnished by Marco Polo in his Travels at the beginning of the fourteenth century. He introduced to the Western world the name Zipangu, transformed from the South Chinese pronunciation of ji pon kuoeh the 'Country of the Sun-Rising Direction'. He himself never actually went to Japan and it was during his travels in South China that he heard of an island country where gold was so abundant that the houses were roofed with golden tiles, a tale that stimulated Christopher Columbus to attempt to find his way to Japan.

Systematic information on Japan began to filter into Europe during the second half of the sixteenth century in the form of reports written by Jesuit missionaries. Outside the order, however, the extent of the diffusion of the information collected by the Jesuits must have been limited; it was not until three centuries later that the order's archives were opened to lay researchers. Between 1582 and 1590, the Jesuits organised a mission to Rome consisting of four youths dispatched by Christian daimyo of 
Kyushu. They arrived in Rome in 1585, and documents preserved in various cities in Italy and on the Iberian peninsula indicate that numerous religious and civil authorities showed a great deal of interest in the country of the Far East represented by the youths. But into the seventeenth century restrictions on travel in and out of Japan were imposed. This was the beginning of the so-called seclusionist policy which actually entailed the monopolisation by the Tokugawa shogunate of cultural and economic intercourse with foreign countries, the latter being limited to China, Korea and the Netherlands. Thus the channel of information through Christian missionaries lasted less than a hundred years.

For over two hundred years, up until the time of the establishment of commercial and diplomatic relationships with Western countries during the 1850s and 1860s, information conveyed from Japan to Western countries was sporadic and extremely limited in quantity and content. The Dutch were confined to the Dutch trading house at Dejima in Nagasaki, but every few years their representatives and accompanying physicians travelled to Edo to pay their respects to the shogun, according to the custom of the day. A German doctor, Engelbert Kaempfer, who worked as personal physician to the Dutch representative at Nagasaki between 1690 and 1692 and accompanied him to Edo, wrote the first comprehensive description of the geography, history and society of Japan, the English translation of which was published in 1727 after his death (the German original was not published until between 1777 and 1779). The work was also translated into Dutch and French and hence in Western countries, for a long period, constituted an important source book pertaining to Japan. In the Jonathan Swift classic, Lemuel Gulliver was shipwrecked and reached the shores of Japan in 1709. He was detained by the authorities and taken to the shogun for interrogation, incidents that happened in reality to a large number of shipwrecked foreigners. Travels in Several Remote Nations of the World by Lemuel Gulliver was published in 1726. It is not clear how Swift acquired his knowledge of Japan, where the prevailing seclusionist policy prevented the exodus from Japan of a great deal of information on Japan; but judging from the accuracy of his descriptions, it is obvious that he had somehow managed to obtain precise information on the country after the banning of Christianity and the deportation of the Christian missionaries.

From 1775-1776, a Swedish botanist and doctor, Carl Peter Thunberg, stayed for one year in Nagasaki, in the capacity of resident physician to the Dutch representative at the Dutch trading house, and published Flora Japonica in 1784. A German physician, Philipp Franz von Siebold, also a physician at the Dutch trading house between 1823 and 1828, transmitted a large amount of information regarding Japan to the West. From the end of the eighteenth century, Japan was menaced by both Russian and American ships which began to appear from time to time in the northern Pacific, emphasising the growing encroachment of outside influences on the closed society of Japan. The shogunate government commenced to show great interest in collecting information on Western countries, subsequently granting Siebold permission to open a school at Nagasaki to teach the Dutch language and medicine to the Japanese who came to him from all parts of the country. Thus he was in a position to extract 
information on Japan from his Japanese disciples who later became pioneers in Western medicine and other forms of Western learning in Japan. In the course of his trip to Edo in 1826, he closely observed what went on around him and, moreover, almost every day measured the latitude and longitude of the places at which he stayed. He brought with him various surgical instruments and a chronometer, and conducted examinations of the sick people he encountered and occasionally performed autopsies. The account of this journey was included in his voluminous Nippon. At Edo, from Kageyasu Takahashi, chief of the astronomical office of the shogunate, he obtained newly completed Japanese maps compiled by Tadataka Ino in exchange for European maps. But the handing over to foreigners of maps of Japan made in Japan was prohibited, and when Siebold was leaving the country the ship transporting his luggage was washed up by a typhoon on an island, and the maps were discovered and confiscated by the Japanese authorities. Kageyasu Takahashi and other high-ranking officials were arrested, most of them being subsequently condemned to death by ritual suicide. However, foreseeing this contingency, Siebold had surreptitiously had copies drawn, and after his return to Europe with the copies, the configuration and position of Japan in European maps came to be rendered with great precision.

As entries in his diary indicate, when Commodore Perry arrived in Japan in 1853 with his East India Fleet to force the shogunate government into opening the country to foreign trade, he already knew a good deal about Japan. The diary reflects the fact that by the middle of the nineteenth century, the Western world had acquired a considerably profound and precise knowledge of Japan from information conveyed by Western travellers in Japan such as Kaempfer and Siebold, and also from information supplied by Japanese survivors of shipwrecks who were rescued by American or Russian ships and taken to America or Russia where they would be stranded for several years, due to the difficulty of getting passage back to Japan.

\section{2 - EARLY TEXTS ON JAPAN BY FOREIGNERS IN MEIJI JAPAN}

Following the lead of the United States, which forced the signing of a friendship treaty on the shogunate government in 1854, Russia, Great Britain and other Western powers signed similar treaties, and Western diplomats were assigned to posts in Japan. Subsequently, in accordance with the commercial treaties concluded with several Western countries in 1858, Japan opened a certain number of ports to trade from abroad and foreign traders began to arrive at the concession reserved for them where they enjoyed extraterritorial rights. However, they were not allowed to travel more than thirty-nine kilometres beyond the perimeter of the concession, except on official business or to attend to diplomatic affairs. The number of foreigners who left accounts of their journeys in Japan was limited: some diplomats who were proficient in Japanese, such as Rutherford Alcock, British envoy, who published The Capital of the Tycoon in 1863, foreign experts providing services in the provinces and vanguard merchants, especially French and Italian merchants, who sought to purchase silkworm eggs in order to cope with the egg shortage, due to disease among silkworms in Europe 
(ZANIER, 1993).

In 1874, the restrictions on inland travel for foreigners were considerably eased, especially in cases of tourism and scientific research. The Meiji government, together with local governments and semi-governmental bodies, invited a host of foreign specialists as consultants, teachers, engineers and so on (oyatoi gaikokujin) who numbered as many as 580 at the peak period in 1875 . For these people, freedom of travel in Japan was highly desirable and also indispensable in the performing of their jobs. We can observe the increased interest in inland travel amongst foreign residents from articles in the Japan Weekly Mail, and the Japan Herald, English-language journals for foreign residents, and in the Transactions of the Asiatic Society of Japan, the organ of the cultural circle of specialists in various fields interested in Japan. The Japanese government ceded to their requests regarding the liberalisation of travel, but failed to obtain in return the amendment of the unequal treaty of 1858 which upheld the extraterritorial rights of foreigners in Japan and denied recognition of Japan's tariff autonomy.

It was towards the second half of the 1870s that increasingly large numbers of accounts of travel in Japan by diplomats, merchants and oyatoi gaikokujin began to be published in Europe and America, which stimulated Westerners to visit Japan as tourists, albeit in the nineteenth-century sense. Most of the travel accounts of this period were used as guidebooks, one example being an account of the journeys of Edward J. Reed (REED, 1880). Another well-read travel account was the Unbeaten Tracks in Japan of Isabella Bird, the nineteenth-century exploratrice sociale (PRATT, 1992), published in 1881 and four editions of this work appeared in the space of a year. She came to Japan for the first time in 1878, at the age of forty-seven. Already famous for her accounts of her travels in Hawaii, she had recently handed into her publisher a new manuscript all about her trip to the Rocky Mountains. Upon her first sight of Yokohama and Tokyo, a curious sensation assailed her; there was something unrealistic about the landscape, it appeared identical to the painted scenes on the fans, ceramics or trays she had seen in Europe, a kind of Oriental stereotype. She wrote that she wanted to travel in the interior of northeast Japan and Hokkaido in order to discover the real Japan. A similar sensation of unrealistic familiarity, a kind of déjà vu, with regard to the landscape also affected Louis Marie Julien Viaud, French naval officer, now better known under his pen-name of Pierre Loti, who arrived at Nagasaki some years later in 1885. In difference from Loti who sought to discover something exotic, romantic and Oriental, staying in cities as he had done in Turkey and Tahiti, Isabella Bird genuinely sought out and pursued her way along unbeaten tracks where no foreigner had ever previously trod. She totally ignored the advice of foreign residents in Yokohama and Tokyo, according to whom the luggage they considered she would need to take with her would require six horses to carry it. As it was, she set out with only three horses, one for herself, one for her assistant and one for her luggage. By around 1880, a stereotyped image of Japan was already beginning to emerge in the writings of foreigners. But Isabella Bird was completely removed from limitations of this sort and wrote of Japan as she saw it and as she felt about it. In fact, her publisher felt compelled 
to ask her to soften her unvarnished accounts of the poverty and ignorance of the Japanese, but she rejected all such requests (RICHIE, 1994). Basil Hall Chamberlain, who lived for forty years from 1877 in Japan, recognised in 1890 that Bird's book remained the best travel account of Japan written in English.

The volume pertaining to Japan of the Nouvelle géographie universelle of Elisée Reclus was published in 1881, and from the details in his descriptions it is clear that he availed himself exhaustively of all these travellers accounts and other information on Japan. This indicates that by the 1870s, the existing quantity of Western-language sources was sufficient for the compilation, one way or other, of a systematic regional Geography of Japan (GIBLIN 1979). He cites the works of Kaempfer and Siebold as the most important among the valuable documents on Japan, but he referred to all of the recent writings of oyatoi gaikokujin such as the observations of Edmund Naumann, German geologist, who calculated the rate of sedimentation of the alluvium forming the delta in the Bay of Tokyo at $27 \mathrm{~cm}$ per century. He also mentions the foundation of the Tokyo Geographical Society in 1879, with its organ Journal of Geography.

Already during the second half of the 1870s, a number of foreign residents, who were members of the Asiatic Society of Japan, had begun to prepare a comprehensive and encyclopaedic guidebook of Japan. They were Ernest M. Satow, British diplomat, who from 1862, stayed several times in Japan; Basil Hall Chamberlain, specialist in Ainu studies and Japanese language and literature; and William Benjamin Mason, then engineer at the Ministry of Communications and later English teacher who died in the 1923 earthquake. Many oyatoi gaikokujin, such as Erwin von Bärtz, professor of medicine at the Imperial University of Tokyo, collaborated in this work. They wanted it to be published as one of the series of Murray guidebooks. A Handbook for Travellers in Central and Northern Japan was published in 1881, and the second edition in 1884, under the editorship of Satow. Though the book was published by Murray, it was not considered a guidebook of the Murray series. The description of Western Japan was not yet completed, and moreover, the book was too thick to be classified as a guidebook, the first edition having consisted of more than 700 pages with innumerable illustrations and notes. It began with a detailed general treatise, actually comprised of the collected papers of the Japanologists of that time. Only upon the publication in 1891 of the third edition, was the book included in the Murray series under the title A Handbook for Travellers in Japan. In the 1891 edition, the number of pages was radically cut to 459 pages, and because Satow transferred to Bangkok as consul general, Chamberlain and Mason took over as editors. Two of the contributors to the 1891 edition were Lafcadio Hearn and Walter Weston, both of whom later became famed in the Western world for their interpretations of Japan. The former was a journalist and writer of stories of Japan, and the latter was a Protestant missionary and author of Mountaineering and Exploration in the Japanese Alps, which inspired the Japanese to adopt the name Nippon Arupusu, the Japanese version of Weston's name for these particular mountains. Until 1913, the Handbook of the Murray series continued to appear repeatedly in revised editions. 


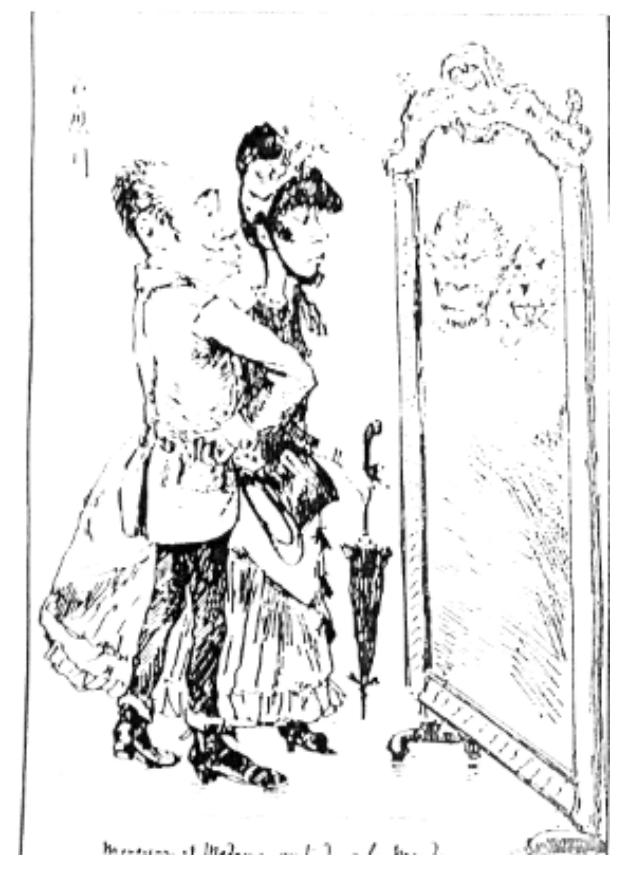

Fig. 1 - Georges Bigot's cartoon of 'Monsieur et Madame vont dans le Monde'. Japanese title at upper left: 'Pretentions'

Fig. 1 - A caricatura de Georges Bigot: 'Monsieur et Madame vont dans le Monde'. Titulo em japonês no canto superior esquerdo: 'Pretentions'

Foreigners have left not only travel accounts and travel guides but also other forms of texts on Japan, comprising pictorial documents, that is, pictures, photographic records, etchings, cartoons and so on. Felice Beato, Corfu-born Venetian, who in 1860, worked as a documentary photographer for the Illustrated London News, following the British and French armies in China, came to Yokohama in 1861, together with British painter Charles Wirgman who was largely responsible for the introduction of modern Western painting in early Meiji Japan. In 1864, Beato opened a photography studio called Yokohama Studio. He contributed greatly to the spread of early photography in Japan and left many valuable pictorial records of the end of the Tokugawa shogunate period and the early Meiji period. Most of his photographs covered the TokyoYokohama area, but he also travelled to many parts of Japan despite the difficulties involved, and took pictures of the people he saw and the places he passed through. Whilst admittedly, his work was affected by a certain exoticism or Orientalism, his photographs, in the main, depicted the lives of the common people (EDEL, 1984). He 
also employed Japanese painters to apply colour to his photographs, adopting a method later utilised in the 1890s by the National Geographic Magazine, which followed his lead in using Japanese painters for many of its photographic illustrations. Judging from the frequent mention of his name and establishment in the Japan Herald and Japan Punch, Beato's Yokohama Studio enjoyed a considerable popularity among foreign residents. In 1871, he followed American troops in Korea compiling photographic reports of their movements, and upon his return to Japan in 1872, he took, and left to posterity, the historic pictures of the opening ceremony of the Tokyo-Yokohama railway, attended by the Emperor Meiji. From 1873, he turned his attention to other businesses, such as speculating in real estate, exporting silkworm eggs and so on, but his endeavours in those lines ended in failure. In 1884, practically bankrupt, he left Japan, but by the 1890s was back in business again, this time in Mandalay and Rangoon, as the owner of F. Beato \& Company, dealers in antiquities and furniture. Because of the unfortunate circumstances of his late years as a photographer, for a long time his work was forgotten in Japan and in other countries. Only in the 1970s was his work re-appraised, first in Italy and the United States, especially on the occasion of the Japan Photographs (1854-1905) exhibit held at the Japan Society Gallery, New York, in 1979. and then in Japan and other countries (ZANNIER, 1986; BERETTA, 1998).

Another long-forgotten artist was Georges Bigot, who came to Japan in 1882. He was a twenty-two-year old French painter, already recognised in France as an illustrator, and was interested in Japanese woodcut prints (ukiyoe). He had barely arrived in Japan when he was overcome by disappointment in the Japanese society of the 1880s, in which the world of ukiyoe no longer existed, and promptly gave up the idea of learning the techniques of woodblock print-making. Japan was undergoing a rapid modernisation, and Bigot grew interested in the curious juxtaposition of traditional Japan and Japan in the process of modernisation. He began to analyse this odd state of affairs pictorially, first through etchings and then through cartoons drawn in ink. His works came to be appreciated by the foreign residents, who became his patrons and customers, and he began to live mainly on his earnings from the sale of his work amongst them. During his eighteen-year stay in Japan, he drew more than three thousand cartoons, the subjects of most of which were Japanese people, and most of which were satirical or critical in nature. He was a very acute and cool observer of the Japanese, but his criticism or satire partly derived from his shared interests with foreign residents of the concession. Though he lived outside the concession at Tokyo in order to observe the Japanese at close hand, his clients continued to be mostly foreigners. Around that time, particularly in the period after the Sino-Japanese war, the Japanese government commenced negotiations with Western countries with regard to the abolishing of extraterritorial rights for foreigners and the Western refusal to recognise Japan's tariff autonomy. The abolishing of extraterritorial rights was strongly opposed by the foreigners in the concession, who took the stand that Japan was not sufficiently civilised to be a party to an equal treaty with Western countries. Some of Bigot's work represented this point of view, especially where he satirised the superficiality of Japanese modernisation and the inferiority complex of the Japanese with regard to 
Westerners. In this respect, we can discover in his work the kind of Orientalist mentality shared by most of the Western residents in Japan, and in some ways by Pierre Loti. Nonetheless, whilst it could be said that Bigot has duly contributed to the creating of a stereotype image of Japanese people - slanted eyes, spectacles, protruding teeth, bow legs - the brunt of his satire was directed at high-ranking bureaucrats, policemen, aristocrats and so on; when he depicted the common people, he emphasised their industriousness and their poverty derived from the stratification of society. Despite the opposition of the foreign residents in Japan, the Japanese government, with the support of the British government, whose ulterior motive in backing Japan was to check the southward advance of Russia, obtained the abolition of extraterritorial rights in 1897, and in 1896 gained partial recognition of Japan's tariff autonomy and full recognition in 1911. Bigot, who once sarcastically remarked that as soon as extraterritorial rights were abolished all foreign residents would be jailed, in fact left Japan in 1899.

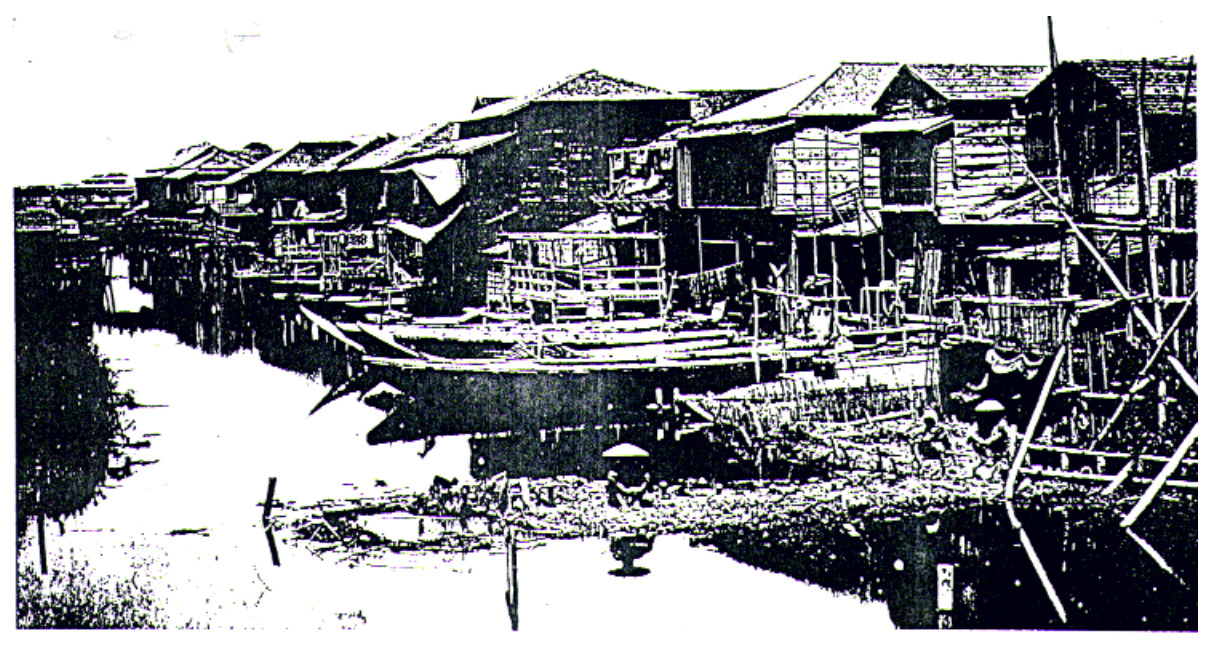

Fig. 2 - Felix Beato's photograph 'The Canal and Market, Gankiro' (1864/65). One of the few surviving views of Yokohama before it was destroyed by fire on November 26, 1866

Fig. 2 - Fotografia de Félix Beato 'Le Canal et le marché, Gankiro' (1864/65)'. Uma das raras vistas de Yokahama, antes da destruição pelo incêndio de 26 de Novembro de 1866

\section{3 - IMPACT OF FOREIGNERS' TEXTS IN THE EARLY MEIJI PERIOD}

The various kinds of texts, travel accounts, scholastic articles, photographic and other visual records made from the beginning of the 1870s undoubtedly differ in character from those of preceding periods. Only at this time did reports on aspects of modernisation begin to appear in earnest, but emphasis was always placed on the 
persistence of traditional Japan, or as seen in the works of Bigot, on the merely skin-deep level of modernisation and the incongruous juxtaposition of the traditional and the modern. Isabella Bird, visited Japan five times after her journey documented in Unbeaten Tracks. Now sixty-nine years of age, she wrote in the preface to the new edition in 1900 that Japan had rapidly changed over the past few decades, especially in aspects of urban life. At the same time, what she had to say regarding the impoverished and miserable situation of Japanese rural life remained unchanged, hence her book continued to be valid as a report on Japan and deserving of re-publication. All these observations, expressed in words and pictures, were indubitably very much to the point. The Meiji Restoration was imperfect and lukewarm as a bourgeois or civil revolution, leaving the countryside smothered under semi-feudal land relationships. The prevailing huge urban and rural poverty restricted the internal market and drove Japanese capitalism into an aggressive war in order to expand the market. Foreigners living for many years in Japan developed a penetrating insight into the contradictions inherent in modern Japan together with the shallow brand of modernisation and the social and cultural dualism resulting from the lukewarm revolution.

The Japanese image abroad was represented in woodcut prints exported in enormous numbers during the Meiji period; many of them coming from the collections of impoverished members of the upper classes who had to sell them in order to eat. The image, which remained little changed up until the end of World War II was added to the stereotype 'Japonica' images, consisting of the bizarre conjunction of the traditional and the modern, and the image of the ugly, cruel and barbaric Japanese soldier. The information based on a deep understanding of and deep insight into Japanese culture and society compiled by a limited number of Japanologists did not reach the masses. For example, in almost all the school textbooks abroad, until World War II, Hokkaido was referred to as Yezo, a name the Japanese had not used since the beginning of the 1870s; in the illustrations, Japanese women always wore kimono, and the pictures were generally of traditional, if not outmoded, aspects, even including samurai with swords. This was naturally due in part to the lingering Orientalist mentality on the Western side, and also reflected the surface-only modernisation and the contradictory realities of the Japan of that period.

Here we have to remark however, that there was one important aspect of modernisation that was by no means superficial and that was successful; but one that neither Japanologists nor foreign travellers, let alone school textbooks abroad, have ever reported on. In order to build the new nation-state, in other words to create the nation or invent the 'imagined community', in the early part of the Meiji period, the Japanese authorities established a land ownership system on the basis of private ownership, and also systematised local administrations, fiscal affairs, compulsory education, military service, communications and so on; in order to realise these projects, they constructed various nationwide infrastructures and imposed standard Japanese, the newly-invented national language, in every corner of Japan, where hitherto, local dialects differed so greatly that people of different localities were unable to understand each other. 
In modern Japan, parallel to the formation of the nation-state and the consolidation of national integration, the awakening among the Japanese people of a consciousness of the 'otherness' or the Orientalist mentality with regard to other Asian people began to take place. 'Leave backward Asia and enter the civilised West' (Datsu-a nyu-o), the motto of Yukichi Fukuzawa, 'enlightenment' thinker and educator of the Meiji period, represents the formation of Japanese Orientalism. For the formation of the image of the other, the Japanese greatly relied on Western Orientalist writings. At the same time, with the exception of a very limited number of intellectuals, they were insensitive to the fact that the Westerners looked on Japan and the Japanese with the Orientalist or Imperial eye (GOTO, 1995).

It was not always that Westerners regarded the Japanese landscape from the viewpoint of an exoticist or Orientalist mentality; in particular, those Westerners who lived in Japan for a long period acquired an insight into things Japanese and viewed the Japanese with their own human sensibility. This was the case of the authors of $A$ Handbook of Travellers, Satow, Chamberlain and others, who were free of the exoticist viewpoint. From the time of the appearance of the first edition, the book was read by the Japanese as well, though the latter were naturally limited to those who were able to read English. Perhaps they chose to read the book because the authors were well-known to them as diplomats, professors and experts in various other fields, and also because among Japanese publications, there was no systematic guidebook of Japan comparable to this book.

In 1894, Shigetaka Shiga, graduate of the Sapporo Agronomical College, published Nihon fukeiron (The Japanese Landscape) which to this day has been widely read over several editions. The contents of this book are generally considered to be an adulatory description of the beauty of the Japanese landscape by means of which, the author wanted to arouse the nationalist sentiments of the Japanese (TAKEUCHI, 1994b).

In common with some other graduates of Sapporo Agronomical College Shiga was deeply interested in geography within the frame of the paradigm of the man-nature relationship and in fact, after 1895, for about twenty years he read geography at the Tokyo Vocational College, the present-day Waseda University. Generally, in the nation-building process, the role of awakening the sense of a shared past is assigned to history as an academic discipline. To geography, as an academic discipline, is assigned the fostering of a sense of belonging to a common national land and Shiga did this through the exaltation of the scenic beauty of Japan. Moreover, the descriptions in Nihon fukeiron are based on the climatological and geomorphological data collected by the newly established nation-wide land survey and the nation-wide meteorological observation network. Shiga emphasises the beauty of the nature proper to Japan. Immediately after its publication, many noted that Shiga's enumeration of beautiful landscapes differed exceedingly from the traditional lists of beautiful landscapes, such as the three most beautiful spots of Japan or eight beautiful spots of such and such a district. The traditional concept of a beautiful landscape called for the qualities of sweetness, harmony and serenity; but Shiga's ideas with regard to scenic beauty involved the wilder aspects of nature such as untamed forests and sheer mountains. In 
the past few decades, many have begun to point out the influence of foreign books on Shiga. For instance, his expressed admiration of the scenic diversity of Japan is undoubtedly a paraphrase of a passage from John Lubbock's The Beauties of Nature and Wonders of the World We Live in, published in 1892, simply substituting the adjective 'Japanese' for 'British'. Shiga's recommendation that scenic beauty be admired from a mountain-top was not his invention but relied on Francis Galton's Art of Travel published in 1885 (YAMAMOTO and UEDA, 1997). Furthermore, a number of descriptions in Nihon fukeiron regarding the orographic beauty of central Japan are literal translations from the second edition of A Handbook for Travellers published in 1884 (ARAYAMA, 1989). Obviously, therefore, Murray's Handbook had a great impact on Shiga in the writing of his book, which in its turn, marked the changing landscape sensibility of the Japanese. We should note, however, that it was not foreigners' descriptions pertaining to Japan that changed the sensibility of the Japanese regarding landscape beauty but the changing sensibility of the Japanese that caused Shiga to adapt the writings of foreign authors in his works. This held true even whilst, in the course of the Westernisation process of the early Meiji period, a large quantity of Western literature, such as the writings of Wordsworth, Ruskin and so on, were introduced in Japan; in fact in 1894, the same year of the publication of Nihon fukeiron, Toson Shimazaki, famed Meiji-period novelist, translated a part of John Ruskin's Modern Painters. The writings of foreigners, then, only partly contributed to the changing landscape sensibility or Westernisation of the aesthetic viewpoint of the Japanese towards the end of the nineteenth century. Naturally enough, as Minamoto and Senda point out, the traditional aesthetic sensibility remained very much in evidence, even in Shiga's iconoclastic Nihon fukeiron (MINAMOTO, 1975; SENDA, 1988).

Prompted by writers such as Shigetaka Shiga, the Japanese adopted the landscape description of Japan formed by Westerners and made it their own. At the same time, the influence of foreign texts lead to the transmitting of the Imperial or Orientalist eye of Westerners to the upper or ruling classes of Japan. Regarding the changing landscape sensibility, what happened in Japan differed, sometimes more, sometimes less, from what happened or is happening in other non-Western countries. In Korea and Northeast China, for instance, it was the Japanese rulers that imposed a city and country planning based on a Western geomorphological conceptualisation, as opposed to the indigenous geomantic conceptualisation of pung-su or feng-shui. Periods of the exaltation of nationalism have occurred in modern Japanese history, but never the exaltation of cultural or religious fundamentalism. Shiga was in a sense nationalist, but he was in the vanguard where the adopting of a landscape sensibility derived from Western alpinism was concerned (SHIBUYA, 1998). An analysis of the articulation of Japanese Orientalism regarding other Asian countries with Western Orientalism in the first half of the twentieth century, in connection with changes in and the persistence of the image of Japan in the Western world, is another task awaiting future exploration.

\section{BIBLIOGRAPHY}


ARAYAMA, M. (1989) - Meiji-ki ni okeru fukei no juyo. Jimbun-Chiri, Kyoto, 41 (6): 63-76.

BARR, P. (1984) - A curious life for a lady: The story of Isabella Bird, traveller extraordinary. Murray, London.

BERETTA, L. (1998) - Felice Beato un fotoreporter nel Giappone dell Ottocento. Studi di Cultura Italo-Giapponese, Tokyo, 36: 14-24.

Bigot, G. (1893) - Japanese album of etchings. Japanese life and character, Yokohama. (Almost all the works of Bigot are in T. HAGA, I. SHIMIZU, T. SAKAI and K. KAWAMOTO, (1989) - Bigot sobyo korekushon 1,2,3. Iwanami Shoten, Tokyo).

BIRD, I. (1881) - Unbeaten tracks in Japan. Putnam, New York (Virago Press, London, 1984).

CHAMBERLAIN, B. H. (1890) - The things Japanese, being notes on various subjects connected with Japan. Kegan Paul, London.

CHAMBERLAin, B. H.; W.B. MASON (1891) - A handbook for travellers in Japan. Murray, London. Kerry \& Walsh Co., Yokohama.

EDEL, C. (1984) - Mukashi-Mukashi. Le Japon de Pierre Loti. Photographies par Beato et Stillfried. Arthaud, Paris.

GIBLIN, B. (1979) - Elisée Reclus (1830-1905). In Geographers: Biobibliographical studies, London, 3: 125-132.

Goto, K. (1995) - Kindai Nihon to Tonan-Ajia: Nanshin no 'shogeki' to 'isan'. Iwanami Shoten, Tokyo.

KÄMPFER, E. (1877-1879) - Geschichte und Beschreibung von Japan aus den Originalhandshriften des Verfassers. Hrsg. von Christian Wilhelm Dohm (Unveränderter Neudruck des 1777-1779. [1964] F. A. Brockhaus, Stuttgart).

MinAmoto, S. (1975) - Shiga Shigetaka no chirigaku. Library and Information Science, Tokyo, 13: $183-204$.

NiCOLAS-OBADIA, G.; H. NOZAWA (1993) - Shigetaka Shiga / Géographie et politique / Espace, science et géographie. Eratosthène, Lausanne.

PRATT, M. L. (1992) - Imperial eyes: Travel writing and transculturation. Routledge, London and New York.

RECLUS, E. (1881) - Nouvelle Géographie Universelle: la terre et les hommes. L'Asie orientale. Hachette, Paris, (Some pages of descriptions of Japan of the 1882 edition are reprinted in P. PINCHEMEL, M.-C. ROBIC, J.-L. TISSIER (1984) (eds.), La géographie française: choix de textes, C.T.H.S., Paris, with biographical notes by G. NICOLAS-O).

REED, E. J. (1880) - Japan: Its history, traditions, and religions with the narrative of a visit in 1879. Murray, London.

RICHIE, D. (1994) - The honorable visitors. Charles E. Tuttle Company, Rutland and Tokyo.

SATOW, E. M.; A.G.S. Hawes (1884) - A handbook for travellers in central \& northern Japan, 2nd edition, Murray, London.

SENDA, M. (1988) - 'Fukei' no nashonarizumu: Shiga Shigetaka to Masaoka Shiki, Nara Joshi Daigaku Chirigaku Kenkyu Hokoku, Nara, 3: 127-143.

SHIBUYA, S. (1998) - Shokuminchi jidai Chosen no chiri shiso no tenkan: Yama no ninshiki o chushin to shite. In N. OSHIRO; M. ARAYAMA (eds.). Kukan kara basho e: 
Chirigakuteki Sozoryoku no tankyu. Kokon Shoin, Tokyo.

SHIGA, S. (1894) - Nihon fukeiron. Seikyosya, Tokyo. (There are the Iwanami Bunko editions of 1937 and 1995, Kodansha Gakujutsu Bunko edition of 1976 and several other editions. Some parts of the text are translated in NICOLAS-OBADIA and NOZAWA's brochure of 1993 on the basis of the 1903 edition.)

SHIMIZU, I. (1981) - E de kaita Nihonjinron: George Bigot no sekai. Chuokoron-sha, Tokyo.

SIEBOLD, P. F. von (1897) - Nippon: Archiv zur Beschreibung Von Japan und desser Neben-und Schutzländern Jeso mit den südlichen Kurilen, Sachlin, Korea und Liukiu - Inseln. Verlag der K.U.K. Hofbuch Handlung von Leo Woerl, Würzburg und Leipzig.

TAKEUCHI, K. (1987) - How Japan learned about the outside world: The views of other countries incorporated in Japanese textbooks, 1868-1986, Hitotsubashi Journal of Social Studies Tokyo, 19: 1-13.

TAKEUCHI, K (1994a) - Nationalism and geography in modern Japan: With special attention to the period between the 1880s-1920s. In D. HoOSON (ed.). Geography and National Identity. Blackwells, London.

TAKEUCHI, K (1994b) - 'The impact of the Japanese imperial tradition and Western imperialism on modern Japanese geography. In GODLEWSKA; A.; N. SMITH (eds.). Geography and empire: Critical studies in the history of geography. Blackwells, London.

TAMAI, T. (1992) - Yomigaeru Meiji no Tokyo - Tokyo 15ku shashinshu. Kadokawa Shoten, Tokyo.

WeStON, W. (1896) - Mountaineering and exploration in the Japanese Alps. Murray, London.

Yамамото, N.; Y. UEDA, (1997) - Fukei no seiritsu: Shiga Shigetaka to "Nihon Fukeiron". Kaifusha, Osaka.

ZANIER, C. (1993) - Alla ricerca del seme perduto. Sulla via della seta tra scienza e speculazione (1858-1862). Angeli, Milan.

ZANNIER, I. (1986) - Verso Oriente. Fotografie di Antonio e Felice Beato. Alinari, Florence. 